\title{
The growth in the use of methane fuel for fuelling urban buses
}

\author{
Jerzy Merkisz ${ }^{1}$, and Maciej Gis ${ }^{2, *}$ \\ ${ }^{1}$ Poznan University of Technology, Institute of Combustion Engine and Transport, Piotrowo Street 3, \\ 60-968 Poznan, Poland \\ ${ }^{2}$ Motor Transport Institute, Environment Protection Centre, Jagiellonska Street 80, 03-301 Warsaw, \\ Poland
}

\begin{abstract}
Urban transport vehicles have a large share in city traffic. This results in higher emission of hazardous substances and poses direct threat for human life by causing smog. Research and implementation works are underway to prevent this situation. In city transport attention is given to electric and hybrid vehicles, as well as gas vehicles that are used. The last group, i.e. city buses with engines fuelled with methane fuels have positive impact on decreasing emission of certain hazardous substances. This article addresses internal tests and their results that confirm the rationality underlying the use of these fuels in city transport buses.
\end{abstract}

\section{Introduction}

The emission of pollution in cities is to a great extent caused by the use of vehicles. The number and age of vehicles and in a sense also other means of road transport, e.g. city buses in a particular area depend largely on the wealth of the inhabitants [1]. For this reason a considerable number of used cars are encountered. Poland is a good example of this phenomenon - the average car age in the country is approx. 15 years.

Another important issue is the fact that transport largely depends on petroleum derivative substances. The share of these fuels in producing energy in transport at the end of the $20^{\text {th }}$ century accounted for as much as $97 \%$ [2]. Since then its share has not changed much $[4,5]$. The combustion of these fuels results in emission of exhaust gases the main components of which include non-toxic substances: nitrogen, carbon dioxide and vapour. Exhaust gases also comprise substances hazardous for people and the natural environment, such as nitrogen oxides, hydrocarbons, particulate matter and carbon dioxide [13].

With the implementation of more and more stringent standards, those emissions are gradually reduced, in particular in road transport [15]. The hazard posed by goods and passenger transport for human health and natural environment can be lessened also by matching types of transport to specific transport tasks [1]. Such approach requires - among others - a comparison of emissions of toxic exhaust gases by different types of buses emitting them. This article discusses comparison tests of city buses. This is essential as there is great likelihood that municipal authorities will limit the traffic of private passenger cars in city

\footnotetext{
* Corresponding author: maciej.gis@its.waw.pl
} 
centres. Therefore, it is necessary to focus on urban transport as city buses will emit hazardous substances in city arteries [14]. This article presents a comparison of hazardous substances emission by city buses with self-ignition engines, fuelled with diesel oil and sparkignition engines fuelled with $\mathrm{CNG}$, in true conditions of road traffic.

\section{Gasification of urban transport}

Fuelling buses with compressed natural gas is becoming more and more popular in Poland. The main component of natural gas is methane, which qualifies it as a methane fuel. Methane and its homologues are flammable components of natural gas. Non-flammable components include e.g. nitrogen or carbon dioxide.

The use of natural gas for fuelling diesel engines has direct impact on the emission of hazardous exhaust substances. The emission levels depend on many factors, including but not limited to the engine construction, its technical conditions, shape and size of the combustion chamber, characteristics of the fuelling system and setting options [3]. Table no. 1 shows some parameters of methane fuel as compared to parameters of the commonly used conventional motor fuels [3].

Table 1. The properties of conventional fuels and alternative gaseous fuels $[6-8,10]$.

\begin{tabular}{|c|c|c|c|c|}
\hline & Gasoline & $\begin{array}{c}\text { Methane } \\
\mathrm{CH}_{4}\end{array}$ & $\begin{array}{c}\text { LPG }\left(\mathrm{C}_{3} \mathrm{H}_{8}\right) \\
\left(\mathrm{C}_{4} \mathrm{H}_{10}\right)\end{array}$ & Diesel \\
\hline $\begin{array}{l}\text { The calorific value of the mixture } \\
\qquad(>=1)\end{array}$ & $\begin{array}{l}-3.7 \mathrm{MJ} / \mathrm{m}^{3} \text { (fuel } \\
\text { from gases) }\end{array}$ & $3.37 \mathrm{MJ} / \mathrm{m}^{3}$ & $=3.66 \mathrm{MJ} / \mathrm{m}^{3}$ & $3.7 \mathrm{MJ} / \mathrm{m}^{3}$ \\
\hline Laminar burning rate $[\mathrm{m} / \mathrm{s}]$ & $0.3-0.6(2-22 \mathrm{um})$ & 0.34 & $\begin{array}{l}\text { 0.39 Prop. } \\
\text { 0.379 But. }\end{array}$ & \\
\hline Air requirement/kg of fuel & $15 \mathrm{~kg} / \mathrm{kg}$ & $17.2 \mathrm{~kg} / \mathrm{kg}$ & $15.5 \mathrm{~kg} / \mathrm{kg}$ & $14.5 \mathrm{~kg} / \mathrm{kg}$ \\
\hline Octane rating & $<98$ & $110-130$ & $100-115$ & \\
\hline Density $\left[\mathrm{kg} / \mathrm{m}^{3}\right]$ relative to air & $(0.72-0.76) \mathrm{kg} / \mathrm{dm}^{3}$ & $0.717 \mathrm{~kg} / \mathrm{m}^{3}$ & \begin{tabular}{|c|}
$2 \mathrm{~kg} / \mathrm{m}^{3} \mathrm{C}_{3} \mathrm{H}_{8}$ \\
$2.7 \mathrm{~kg} / \mathrm{m} \mathrm{C}_{4} \mathrm{H}_{1 \mathrm{O}}$
\end{tabular} & $\begin{array}{c}0.86 \\
\mathrm{~kg} / \mathrm{dm}^{3} \\
\end{array}$ \\
\hline Flash point $\mathrm{T} 21\left[{ }^{\circ} \mathrm{C}\right]$ & $\begin{array}{c}\text { Normal } 220^{\circ} \mathrm{C} \\
\text { Super } 270^{\circ} \mathrm{C} \\
\text { Jet }-400^{\circ} \mathrm{C}\end{array}$ & $650^{\circ} \mathrm{C}$ & $\begin{array}{l}4819 \mathrm{C}_{2} \mathrm{H}_{10} \\
4309 \mathrm{C}_{4} \mathrm{H}_{10}\end{array}$ & $220^{\circ} \mathrm{C}$ \\
\hline Flammability range (practical) $K$ & $0.7-1.25$ & $0.6-1.9(2)$ & \begin{tabular}{|c|}
$0.4-1.91 \mathrm{C}_{3} \mathrm{H}_{8}$ \\
$0.34-1.74$ \\
$\mathrm{C}_{4} \mathrm{H}_{10}$ \\
\end{tabular} & $0.19-0.98$ \\
\hline Explosion limit & $(1.3-7) \%$ & $(5-15) \%$ & $\begin{array}{c}(2.12-9.35) \% \mathrm{P} \\
(1.8-8.5) \% \mathrm{~B}\end{array}$ & $0.6-6.5 \%$ \\
\hline
\end{tabular}

CNG-fuelled engines characterise with unvarying operation, which brings reduced noise emission as compared to noise emitted by engines fuelled with conventional fuels [3]. The use of - among others - CNG to fuel city transport buses has a number of advantages compared to diesel oil, for example as regards the usually very low emission of particulate matter, advantageous road emission of nitrogen oxides, without the use of any additional exhaust filtering systems.

The pros and cons of using CNG as a fuel for fuelling bus engines are proved by tests conducted on the chassis dynamometer of heavy vehicles in West Virginia University. The tests involved eight Orion buses with diesel engines and CNG engines (three CNG buses with John Deere RGG081 engines (poor mixture), three CNG buses with Cummins CG-280 
engines (stoichiometric mixture) and two buses with Detroit Diesel Corporation engines (DDC)) [11]. The tests included 16 driving cycles and one idle-run cycle [11].

The tests proved that except for hydrocarbon emissions the tested vehicles characterised with a similar emission of $\mathrm{NO}_{\mathrm{x}}$ and $\mathrm{PM}$. The $\mathrm{CO}$ emission was low for buses with a selfignition engine and for buses with John Deer (CNG) engines. However, buses with Cummins (CNG) engines emitted more carbon oxide. Carbon dioxide emission was lower for CNGfuelled buses by approx. $20 \%$ compared to self-ignition engines as a result - as claimed chemical properties of fuel. The methane emission from the exhaust system in the tested buses fuelled with CNG ranged from 4 to $47 \mathrm{~g} / \mathrm{km}$, on average $12 \mathrm{~g} / \mathrm{km}$ for buses with JohnDeere engines and $21 \mathrm{~g} / \mathrm{km}$ for buses with Cummins engines $[11,16]$. Nevertheless, the results of the tests do not reflect fully the results of tests in true conditions of road traffic.

Vehicles fuelled with natural gas are popular in a number of countries, e.g. Pakistan, Iran, Argentina, Brazil, India or in Europe - in Italy. For instance by the end of 2011 there were over 14 million of such vehicles across the world, including more than 430.000 of buses. In Poland their number was estimated at roughly 2000, including c.a. 270 buses [9]. At present the number of buses is estimated at approx. 400. At the end of 2011 there were almost 20700 natural gas filling stations (presently approx. 26700 stations) worldwide, 33 public stations in Poland, while currently there are less although 52 new stations to be built are planned [9].

The greatest fleet of CNG-fuelled buses in Poland is in Tychy. The bus transport fleet of the city has approx. $73 \%$ of vehicles with $\mathrm{CNG}$-fuelled engines, i.e. more than 70 CNG-fuelled buses [12].

\section{Internal tests}

The rationality of using methane fuels in urban transport is confirmed by internal tests comprising articulated city buses of Euro VI emission level in true traffic conditions. One of the tested buses was powered with a self-ignition engine. The other was powered with a CNG-fuelled engine. The basic engine parameters of the tested buses were as follows: self-ignition engine - engine displacement $\mathrm{V}_{\mathrm{ss}}=10.5 \mathrm{dm}^{3}$ and nominal power $\mathrm{N}_{\mathrm{zn}}=235 \mathrm{~kW}$, CNG-engine displacement $\mathrm{V}_{\mathrm{ss}}=12,8 \mathrm{dm}^{3}$ and nominal power $\mathrm{N}_{\mathrm{zn}}=228 \mathrm{~kW}$.

\subsection{Devices and the test route}

Internal tests were performed with the use of mobile PEMS measuring devices on urban routes where the tested buses are used on a daily basis.

The exhaust gases emission and fuel consumption of two buses had been measured in a range of driving conditions. The emission of hazardous exhaust substances and fuel consumption were compared owing to measurements made with two devices. Both vehicles moved one after another, which allowed for eliminating errors due to driving style or changeable weather conditions.

The test route combined elements of urban and extra urban (Fig. 1). Parameters of the test route are represented in Table 2. 


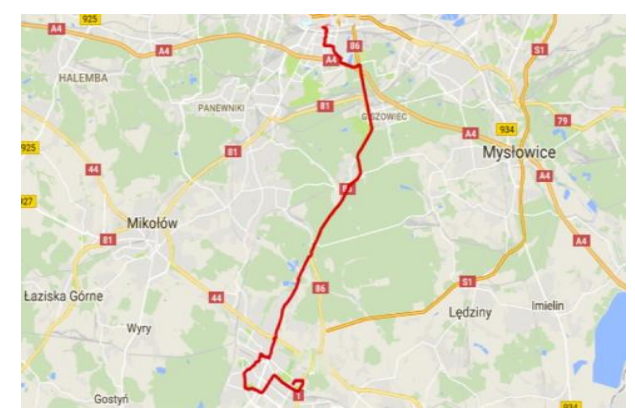

Fig. 1. Test route consisting urban and extra urban part.

Table 2. Characteristics of test route.

\begin{tabular}{|c|c|}
\hline \multicolumn{2}{|c|}{ Test route } \\
\hline Length & $26 \mathrm{~km}$ \\
\hline Change of altitude & $\begin{array}{l}\text { minimum } 183 \mathrm{~m} \\
\text { maximum }-178 \mathrm{~m}\end{array}$ \\
\hline Max. slope & $4.7 \%$ \\
\hline Min. slope & $-6.9 \%$ \\
\hline Average positive slope & $1.3 \%$ \\
\hline Average negative slope & $-1.3 \%$ \\
\hline
\end{tabular}

\subsection{Test results}

The tests were performed with the use of two mobile PEMS devices. The results could be compared because the tests had been conducted simultaneously. For this reason the impact of weather and the driver can be omitted. To better verify the similarities of tests a summary of respective driving phases of both tested buses was provided as shown in Table 3.

Table 3. Values of respective driving phases of tested buses.

\begin{tabular}{|c|c|c|c|}
\hline & Value & $\begin{array}{c}\text { Bus powered } \\
\text { by CNG fuel }\end{array}$ & $\begin{array}{c}\text { Bus powered } \\
\text { by diesel fuel }\end{array}$ \\
\hline Acceleration & $\%$ & 38 & 40 \\
\hline Fixed velocity & $\%$ & 19 & 9 \\
\hline Braking & $\%$ & 28 & 35 \\
\hline Stopover & $\%$ & 15 & 17 \\
\hline
\end{tabular}

With the test results, it was possible to determine the content and intensity of flow, depending on the route. Fig. 2 presents the results for $\mathrm{CO}_{2}$ with reference to the road, for both tested cities buses.

Studies also permitted to determine the present temporary and average fuel consumption, also with reference to the route of both vehicles (fig. 3). 

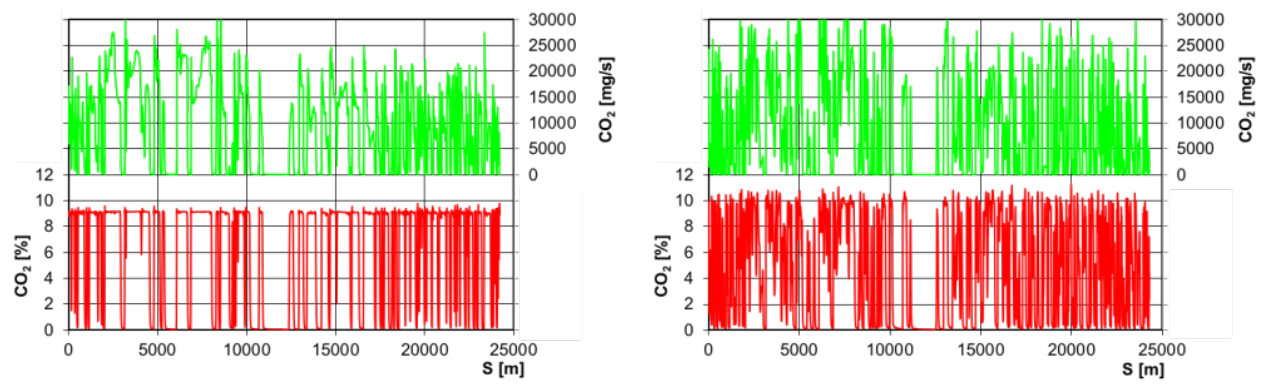

Fig. 2. Concentration and intensity of $\mathrm{CO}_{2}$ emission with reference to the completed road: I bus - left (CNG-fuelled), II bus - right (diesel fuelled).
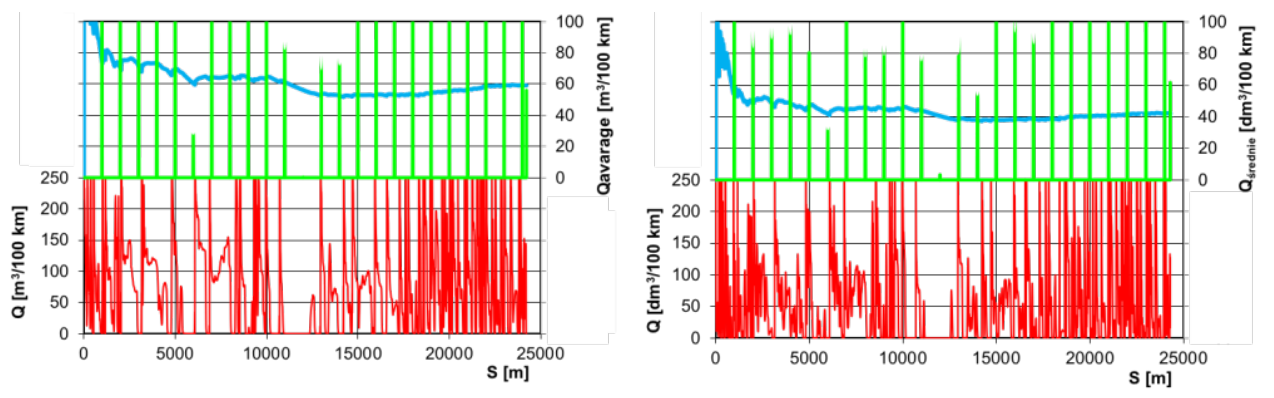

Fig. 3. Characteristics of temporary and average fuel consumption with reference to the completed road: I bus - left (CNG-fuelled), II bus - right (diesel fuelled).

Owing to the tests it was possible to determine time courses for the intensity of emission of hazardous substances of exhaust gases for both buses. Hense, correlations were developed characterising the impact of dynamic properties of public transport buses on the emission of harmful compounds. Dynamic properties of vehicles were included indirectly, using the entire velocity range and the range of measured acceleration in urban traffic for a matrix of intensity of emissions of respective pollutants. Those figures were averaged in respective velocity and acceleration ranges.

Therefore, characteristics of operation in respective ranges and the matrix of emission of harmful compunds had been determined.

According to data presented in Fig. 3 there is a similarity in the portion of operating time for the tested buses. Also, a greater portion of operation is observed in the area of minimum driving speed (stopover) and high driving speeds $(10-18 \mathrm{~m} / \mathrm{s})$ and zero bus acceleration.
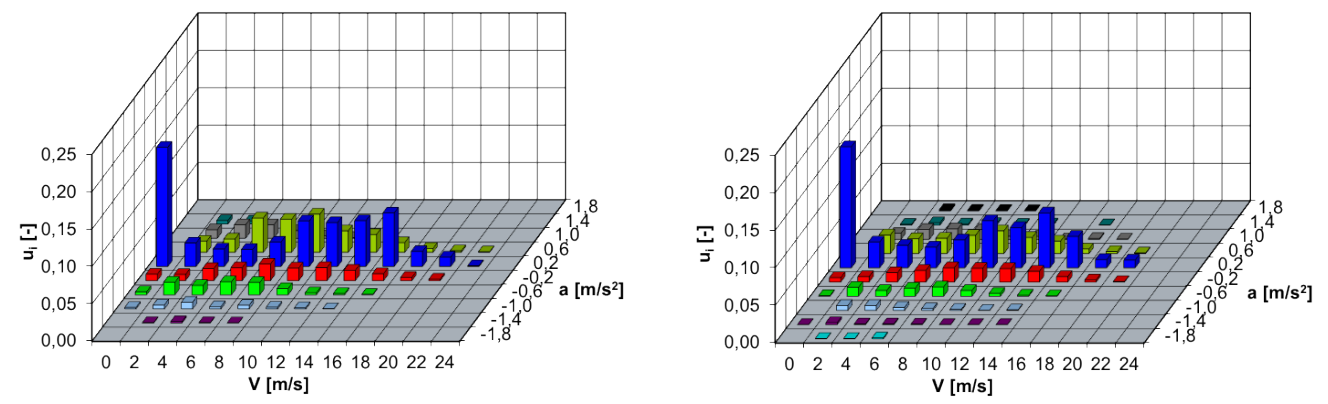

Fig. 4. Two-dimensional histograms of vehicle's operating time in relation velocity - acceleration: I bus - left (CNG-fuelled), II bus - right (diesel fuelled). 
Two-dimensional histogram of intensity of $\mathrm{CO}_{2}$ emission $[\mathrm{mg} / \mathrm{s}]$ in the relation velocity acceleration is presented in Fig. 4. It represented indirectly the fuel consumption during the tests. The bus fuelled with CNG was comparable. Histograms of intensity of $\mathrm{CO}_{2}$ emission during the tests for averaged velocities are represented in Fig. 5.
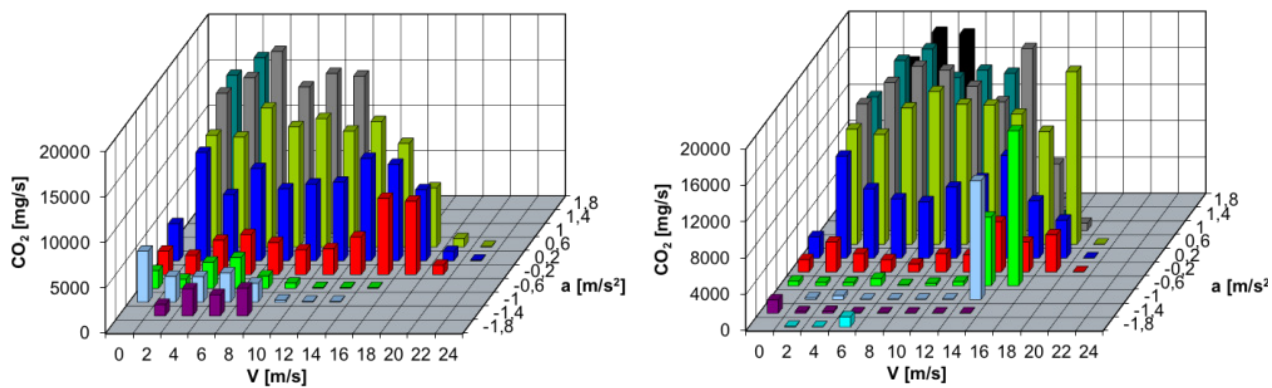

Fig. 5. Two-dimensional histograms of $\mathrm{CO}_{2}$ emission intensity during the tests in relation velocity - acceleration: I bus - left (CNG-fuelled), II bus - right (diesel fuelled).

In case of the CNG-fuelled bus, attention must be given to $\mathrm{NO}_{\mathrm{X}}$ emission, which is lesser than in the diesel-fuelled bus. Fig. 6 presents a two-dimensional histogram of $\mathrm{NO}_{\mathrm{X}}$ emission intensity during the tests in the relation velocity - acceleration.
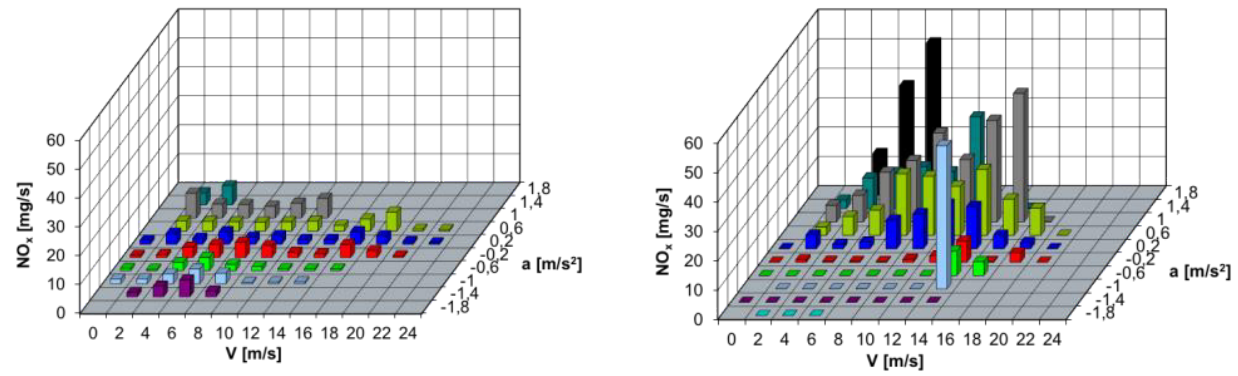

Fig. 6. Two-dimensional histograms of $\mathrm{NO}_{\mathrm{x}}$ emission intensity during the tests in relation velocity acceleration: I bus - left (CNG-fuelled), II bus - right (diesel fuelled).

Also, in case of $\mathrm{HC}$ emission intensity, the CNG-fuelled bus manifests lower emission than the diesel-fuelled bus. This is reflected in Fig. 7.
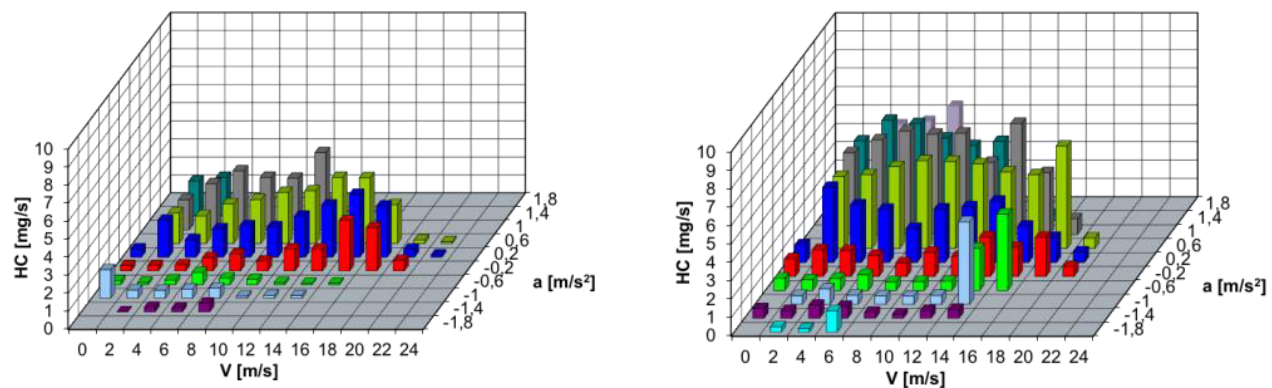

Fig. 7. Two-dimensional histograms of hydrocarbons emission intensity during the tests in relation velocity - acceleration: I bus - left (CNG-fuelled), II bus - right (diesel fuelled). 
Fig. 8 presents a comparison of the results of fuel consumption and exhaust emissions during tests.

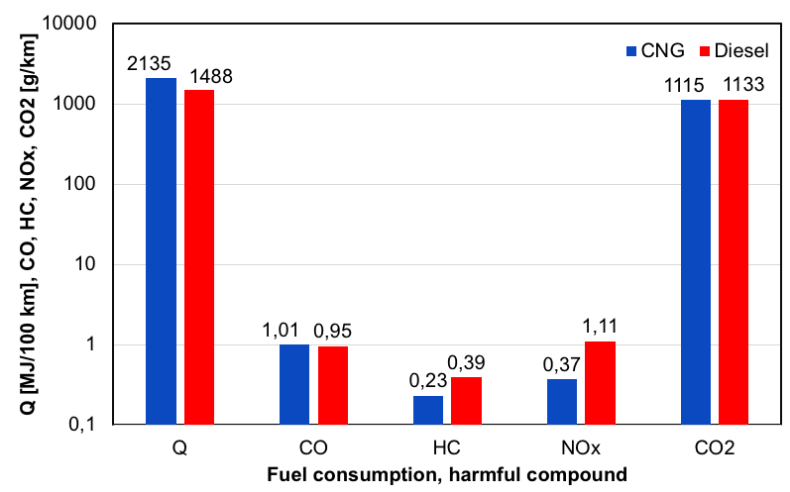

Fig. 8. Comparison of fuel consumption and emission of exhaust gases during tests: - I bus (CNGfuelled), - II bus (diesel fuelled).

\section{Conclusions}

The following conclusions follow from tests in true conditions of road traffic:

- fuel consumption (natural gas): approx. $2135 \mathrm{MJ} / 100 \mathrm{~km}$ (CNG-fuelled bus) and approx. $1488 \mathrm{MJ} / 100 \mathrm{~km}$ (diesel-fuelled bus);

- CO emission: $1.01 \mathrm{~g} / \mathrm{km}$ (CNG-fuelled bus) and $0.95 \mathrm{~g} / \mathrm{km}$ (diesel-fuelled bus) increase by $\sim 6 \%-\mathrm{CNG} / \mathrm{ON}$ ratio),

- hydrocarbons emission: $0,11 \mathrm{~g} / \mathrm{km}$ (CNG-fuelled bus) and $0.39 \mathrm{~g} / \mathrm{km}$ (diesel-fuelled bus) - decrease by $\sim 40 \%$,

- nitrogen oxides emission: $0.37 \mathrm{~g} / \mathrm{km}$ (CNG-fuelled bus) and $1.11 \mathrm{~g} / \mathrm{km}$ (dieselfuelled bus) - decrease by $\sim 67 \%$,

- $\mathrm{CO}_{2}$ emission: $1115 \mathrm{~g} / \mathrm{km}$ (CNG-fuelled bus) and $1133 \mathrm{~g} / \mathrm{km}$ (diesel-fuelled bus) decrease by $\sim 1.6 \%$.

The results of the road tests prove that the use of methane fuel such as CNG in city buses can be beneficial in terms of emissions of hydrocarbons and nitrogen oxides.

In the Law on electromobility and alternative fuels (Law of January 11, 2018), compressed natural gas (CNG), including biomethane from $\mathrm{CNG}$, is considered to be an alternative fuel. The minister responsible for energy prepares the National framework for the development of alternative fuels. The national framework includes in particular:

- national target for the number of refueling points for compressed natural gas (CNG),

- list of municipalities and transport networks in which, taking into account market needs, refueling points for compressed natural gas $(\mathrm{CNG})$ are to be deployed.

The minimum number of CNG refueling points located in municipalities until December 31,2020 shall be at least:

- 6 in communes (population $>1,000,000$, registration of at least 60,000 motor vehicles and per 1000 inhabitants there are at least 700 motor vehicles);

- 2 in communes (population> 100,000, registration of at least 60,000 motor vehicles and per 1000 inhabitants there are at least 400 motor vehicles).

The number of CNG refueling points includes CNG refueling points located along the TEN-T core network. 
It should be assumed that currently in Poland we are at an essential moment in the development of the use of CNG in road transport.

\section{References}

1. M. Witaszek, K. Witaszek, Zeszyty Naukowe Politechniki Śląskiej 87, 105-112 (2015)

2. Baseline energy statement - energy consumption and carbon dioxide emissions on the railway (The Voice of the passenger railway, 3, 2007).

3. www.cng.auto.pl (2018)

4. H.L. MacLean, L.B. Lave, Prog. Energ. Combust. 29 (2003)

5. K. Mäkelä, Sci. Total Environ. 169 (1995)

6. Directive 2005/55/EC of the European Parliament and of the Council of 28 September 2005 on the approximation of the laws of the Member States relating to the measures to be taken against the emission of gaseous pollutants from positive - ignition engines fuelled with natural gas or liquefied petroleum gas for use in vehicles. Official Journal of the European Union L 275/1 (2005)

7. M. Gis, Ograniczenie emisji dwutlenku węgla z silników spalinowych pojazdów kategorii M i N przez zastosowanie biometanu (Engineer's thesis, 2013)

8. W. Gis, A. Żółtowski, A. Majerczyk, S. Taubert, (ITS Study, 6105/COŚ, 2011)

9. Gas Vehicle Report, 10 (2011)

10. Commission Regulation (EC) No. 582/2011 of 25 May 2011 implementing and amending Regulation (EC) No. 595/2009 of the European Parliament and of the Council with respect to emissions from heavy-duty vehicles (Euro VI) and amending Annexes I and III to Directive 2007/46/EC of the European Parliament and of the Council. OJ L $167 / 1(2011)$

11. N.O. Nylund, K. Erikkilä, N. Clark, G. Rideout, Final report of IEA AMF Annex XXIX (2007)

12. pkmtychy.pl (2017)

13. Z. Stelmasiak, J. Larisch, J. Pielecha, D. Pietras, Pol. Marit. Res. 2, 24 (2017)

14. J. Merkisz, M. Idzior, J. Pielecha, W. Gis, Urban Transport XVI-Urban Transport and the Environment in the 21st Century (WIT Press, Wessex, 2010)

15. J. Pielecha, J. Merkisz, J. Markowski, R. Jasinski, Analysis of passenger car emission factors in RDE tests (International Conference on the Sustainable Energy and Environment Development, SEED, 2016)

16. J. Markowski, J. Pielecha, R. Jasiński, T. Kniaziewicz, P. Wirkowski, Development of alternative ship propulsion in terms of exhaust emission (International Conference on the Sustainable Energy and Environment Development, SEED, 2016) 